\title{
Editorial: Designing Urban Living
}

\section{WENDY HARCOURT}

Earlier this year I visited Beijing with my family on a short stopover en route from Sydney to Rome. We found ourselves, in between visits to the Great Wall and temples, in a city of huge and competing modern architectural feats. Beijing was a riot of experiments in diverse building styles all in glass and steel jostling along traffic filled roads from the Birds Nest Stadium of Olympic fame to the New Poly Plaza and the World Trade Center. Along with massive shopping plazas and neon-lit night life there was an ultra modern subway complete with an English friendly design that shamed the Rome metro. The restaurants we visited near our hotel were with plasma-screened televisions, and fashionably clad Chinese youths with micro phones who called in our order. It was bewilderingly fast and modern dominated by the buildings that shouted wealth.

Where were the bicycles and the people? We found some in non-English signed streets, peddling old bicycles with baskets of hot drinks and dumplings (it was January) and in street markets and kiosks trading vast assortments of household gadgets and clothes. One had no sense at all of where people lived, nor of what was distinctly Chinese about all these buildings, indeed on investigation it turned out many of the architects were westerners from Europe and US who were experimenting with the flush of Chinese money and power.

The city was about empire, wealth and power, not a city designed to sustain ordinary Chinese lives. The car choked streets, the pollution, the sprawl and the iconic rather than people-centred buildings were clear in their messages.

This journal issue on sustainable cities suggests that the trend for most cities in the Global South is towards the fast, modern and big, all designed to attract world trade, foreign money, high tech businesses, tourists and high consumer living for the rich. The city is devoted to cars and business, tourists receive a Disney world glimpse of what 'was', the ordinary people, the workers, are on the fringes: in the high rises if middle class, or in the slums, or, if very poor, living on the streets.

Since 2008, more than half the world's population is living in towns and cities, with Asia and Africa leading the way. Urban development has become a human development issue. The glamour and underside of mega cities, like Beijing, have captured the most attention. We are well aware of the ugliness of life on the streets, the huge contrasts of the life of an itinerant migrant begging for coins off a visiting rich tourist, all overwhelmed by vast spaces and iconic cities that dwarf the people that dwell in them.

However, the reality is that the majority of the new growth will occur in smaller towns and cities. Asia and Africa in particular are experiencing rapid rural to urban migration and often to smaller towns need to plan for the influx. As many of the articles 
point out in this issue it is in these smaller towns and cities where hope of achieving sustainability lies. It is in the urban centres of Africa and Asia, East Europe and the Middle East where civil action groups, town planners and local government at the community level try to ensure urban life is redesigned for people and their well-being, security and safety. It is here where new forms of energy, transport, water and sewerage are designed with social and cultural and gendered needs in mind so that the city environments sustains creative, comfortable eco-aware 'good' lives.

The articles from Africa, Asia and the Pacific, Latin America, Europe and the Middle East illustrate how these are the main concerns of sustainable cities. Even within the biggest cities, like Istanbul or Paris or Mumbai there are experiments going on among government, business and civil society that are trying to adjust to today's urban realities that push beyond star architecture, city branding and aim to provide better water, housing, transport and services. The articles speak of decentralization, safety and security, making cities safe for women, how to overcome the threat of climate change, dislocation and migration, and find ways of surviving well.

But among the potential experiments for better living for people in urban environs, there is also the note of strain, of environmental and social threats, of the non sustainability of city life. Slums are on marginal land, subject to earthquakes, floods, land-slips and erosion with over crowding as many come in from the countryside to escape war and/or find employment and build shelters on land without legal title. In this context the concept of sustainability is evoked to define limits of life in cities today, the growing inequalities, increasing poverty, collapsing ecosystems and the need to regenerate and restore just economics, living cultures and environments. Sustainable cities are a hope for the future.

In achieving this future, the articles remind us how important it is that we change our development narrative from fast track growth, modernity, high rise, high tech, cyberspace living, to resilient economies striving for more equal, more inclusive societies more gender aware with more public services, more social protection and more democratic participation of employees and consumers. We need to redesign ways of living, cultures, societies and economies to bring cities to the level of people who live in them. It is the finiteness of the planet and our need to connect with each other that should determine our environmental, social and financial needs.

These voices and experiments show what is possible in multiple places from the Solomon Islands in the Pacific, Bucharest in Eastern Europe, Peru in Latin America, Mumbai in India. All speak of the need to change current ways of living and of urban centres that provide services, respect ecological limits and foster peoples' needs. The challenge now is to build sustainable urban living based on peoples and community, and an ethics of care for culture and the environment.

The authors echo Susan George (2010) when she argues that we need a different grand narrative we can believe in, that is, that the world is rational and beautiful with enough space and good life for all. We need to move away from the grand narrative of power and people-decentred architecture that dominate the iconic mega cities of today. We need to find ways to redefine capitalism aware of social and ecological limits. This means replacing star architecture that so dominates cities like Beijing to urban environments that are designed to keep us connected and respecting others, our diverse cultures and the planet.

In the next issue of Development to complete the volume on sustainability we turn to 'cosmovisions' an alternative to dominant narratives of development coming out of Latin America. Development Volume 54, no 4 will look at ways to resist and reshape western patriarchal neo-liberal capitalist development. It will complete Development's look at sustainability with a look at buen vivir and ethical, indigenous and feminist proposals for alternatives to development.

\section{Reference}

292 George, Susan (2010) Whose Crisis Whose Future? Towards a Greener, Fairer and Richer World, Cambridge: Polity Press. 